\title{
Problems and Countermeasures of International Trade Financing of Small and Medium-Sized Enterprises in China
}

\author{
Zhenjun $\mathrm{Wu}^{*}$ \\ Fuzhou Technology and Business University, Fuzhou 350000, China \\ *Corresponding author: Zhenjun Wu, 1016970049 @qq.com
}

\begin{abstract}
Small and medium-sized enterprises are the foundation of China's national economy, and they are important forces to promote economic and social development. They play an irreplaceable role in promoting scientific and technological progress, increasing social employment, expanding foreign trade, and other aspects in which they have become an important part of China's socialist market economy. Based on the research background of international trade financing, this paper analyzes the problems existing in the international trade financing of small and medium-sized enterprises in China to put forward countermeasures and suggestions, hoping to help these small and medium-sized enterprises solve the financing problem so as to achieve a healthy development in the international trade market environment.
\end{abstract}

Keywords: Small and medium-sized enterprises; International trade; Financing; Countermeasures and suggestions

Publication date: August 2021; Online publication: August 30, 2021

\section{Introduction}

In recent years, with the continuous improvement of the socialist market economy, small and medium-sized enterprises in China have been able to participate in international competitions under relatively fair conditions in addition to the expansion of their export volume and utilization of foreign direct investment (FDI). However, the difficulty of financing has restricted these enterprises, hence it is urgent to solve this financing problem. Only by effectively solving the financing problem, then the development potential of small and medium-sized enterprises can be brought into light while making them play a greater role in the economic and social development.

\section{Main problems of small and medium-sized enterprises in international trade financing}

\subsection{High financing access threshold and complex approval process}

Most of the financing institutions for small and medium-sized enterprises are banks. However, due to the high requirements of bank loans for enterprises, small and medium-sized enterprises cannot meet the credit needs of the banks, which makes it difficult for them to obtain sufficient funds from banks. In addition, the examination and approval procedures in the process of international trade financing are relatively complex with long periods and low efficiency, which also affects the process of international trade financing and the economic activities of small and medium-sized enterprises. This further increases the difficulty of international trade financing for small and medium-sized enterprises. 


\subsection{Insufficient credit conditions of small and medium-sized enterprises}

The credit status of small and medium-sized enterprises is directly related to the difficulty and success of financing. At present, small and medium-sized enterprises in China generally have poor anti-risk capability due to small scale, weak capital strength, limited investment in research and development, access to market information lag, as well as poor management. Many small and medium-sized enterprises pay attention to corporate profits and ignore their own management. Most small and medium-sized enterprises have not established a complete set of financial management system along with the development of enterprises. In addition, the shortage of capital and the lack of credit file records have greatly affected their commercial credit, which then affects their qualification to obtain international trade financing.

\subsection{Imperfect trade financing system in China}

From the reform and opening up to China's accession to the WTO, China's foreign economic and trade pattern has established a financing system from scratch. Although it is constant, there are still many areas to be improved. More attention should be paid to the construction of trade financing support market, the main body of the market, and trade financing supervision system. Only in this way, small and mediumsized enterprises can be assisted in international trade financing.

\subsection{Lack of professional talents}

International trade financing of small and medium-sized enterprises in China started late, hence they lack high-quality staffs. From the perspective of most enterprise teams, the transformation of domestic sales is relatively common, and it is difficult to compare with the professional ability of senior managers and highquality export sales personnel as they have little knowledge about trade financing and bank loans. This kind of poor professional ability of talents has seriously affected the financing work of small and medium-sized enterprises.

\subsection{Weak internal management of small and medium-sized enterprises}

Profit and good management are the keys for enterprises to attract funds. However, with the development of small and medium-sized enterprises, there are losses, poor management, mortgage, and other problems. These unhealthy phenomena result in the occupation of bank assets, leading to credit risks, which is not only conducive to the circulation of bank funds, but also affects the trade financing of small and mediumsized enterprises.

\subsection{Complex and changeable international trade environment}

International trade is a form of economic activity that connects countries and regions with different ideologies. Nevertheless, due to the differences in law, geography, and religion of different countries and regions, there are still a variety of international factors that affect China's international trade from time to time and also invisibly increase the trade financing risks of small and medium-sized enterprises, which hinder the deep integration and synchronous development of regional economies. In addition, the market environment is complex and changeable. While small and medium-sized enterprises do not have the ability or channel to collect and identify complete international trade information, their decision-makings are prone to mistakes. This leads to doubts from investors about the enterprises' future development, which increases the difficulty of enterprise financing. 


\section{Root causes of the problems in international trade financing of small and medium-sized enterprises}

\subsection{Level of small and medium-sized enterprises}

Small and medium-sized enterprises are generally defined as smaller or entrepreneurial and growing enterprises, most of which are private enterprises. The managers of these enterprises have different management concepts, and their management efficiency as well as quality are more different. They are extremely vulnerable to the impact of the market and international economic fluctuations. In addition, the trade risks they bear are much higher than those of large enterprises. At the same time, small and mediumsized enterprises do not pay enough attention to financial administration and management, lack perfect internal control standards, and some even have financial administration and management loopholes, which affect the enterprises' credit, hence unable to successfully complete financing activities, such as loans. In addition, compared with large enterprises, small and medium-sized enterprises have a higher probability of high assets and liabilities, which also increases the difficulty for these enterprises to apply for financing from financial institutions.

\subsection{Level of financial system}

Banks currently play a dominant role in the financial system, but the loans that small and medium-sized enterprises receive from financial institutions and banks do not match their proportion in the national economy. Generally speaking, the conditions for banks to extend loans to enterprises are extremely strict, taking into consideration of the enterprises' scale, profitability, net assets, guarantee ability, and other indicators. However, the frequent fluctuations of finance and capital, as well as the loopholes in management and operation of small and medium-sized enterprises mean that the lending risks for banks are relatively higher along with the comparison of the above indicators of small and medium-sized enterprises with those of large enterprises. It is true that small and medium-sized enterprises are in disadvantageous positions, and their lending is naturally at a disadvantage. Therefore, it is difficult for small and mediumsized enterprises to obtain funds from banks, and they will inevitably need to choose other financial institutions for loans, which significantly increases the financing costs and risks. At the same time, due to the strict administration and management of initial public offerings (IPOs) in China, the direct financing (equity financing) channel of small and medium-sized enterprises is not smooth.

\subsection{Level of government}

First of all, the laws and regulations related to the financial and international trade activities of small and medium-sized enterprises are not perfect enough. At present, there are many policy supports for large enterprises in China, but a complete policy system to support the development of small and medium-sized enterprises has not been formed, which indirectly leads to the difficulty of trade financing for small and medium-sized enterprises. Secondly, China is yet to establish a perfect financing service system for small and medium-sized enterprises. At present, guarantee agencies are mainly used to provide financing support for small and medium-sized enterprises. However, the management of these guarantee agencies is not mature, and there are no financial institutions that are specialized in serving small and medium-sized enterprises, which affects the improvement of the financing service system for small and medium-sized enterprises.

\section{Suggestions on international trade financing of small and medium-sized enterprises in China}

\subsection{Improve the overall quality of small and medium-sized enterprises}

Small and medium-sized enterprises should recruit more innovative talents in the fields of management and 
technology to drive breakthrough innovations, change the traditional mode of operation and management, set up modern enterprise systems, establish and improve the accounting system, standardize financial institutions of international trade financing in order to gain financial support as well as guarantee the longterm development of these enterprises.

Small and medium-sized enterprises can adjust their business strategies from various aspects. First, improve the risk prediction ability. Forward-looking risk prediction ability can improve the enterprises' risk awareness in coping and prevent possible risks in the future so as to avoid loss of properties caused by sudden accidents, which would greatly reduce the enterprises' credit and affect the financing. Second, more attention should be paid to the innovation of products and services. Under the premise of ensuring quality, small and medium-sized enterprises should innovate original technologies, develop new products, and open-up new businesses to bring-in new profit points and improve their comprehensive strength. Thirdly, it is necessary to cultivate high-quality talents in international economy and trade, effectively integrate enterprise resources, and enhance enterprise strength.

Along with the requirements of the modern enterprise system, qualified small and medium-sized enterprises should adjust their internal organizational structures, standardize their governance structures, strengthen financial managements, improve their accounting systems, ensure that their accountings truly and accurately reflect their business processes and results, establish and improve internal control management systems, and ensure the separation of incompatible posts in order to improve their international trade financing ability.

\subsection{Increase the support from financial institutions}

The support from financial institutions affects the success or failure of international trade financing of small and medium-sized enterprises. In order to improve the support from financial institutions, begin from the innovation of international trade financing products by financial institutions, then create a platform that keeps pace with the times and develops with international trade. In terms of specific measures, financial institutions should increase the research on international trade financing products, improve their own professionalism, design a wealth of targeted products for international trade financing of small and mediumsized enterprises, as well as actively carry out new financing businesses; that is, to design according to the actual needs of their customers, carry out diversified combinations of trade financing products, and promote the realization of international trade financing of small and medium-sized enterprises.

The international trade business has the advantage of self-compensation and is less risky compared to general trade financing. Therefore, it is necessary for banks to make policy preference for it when formulating relevant financing and credit policies. By providing certain preferential strategies to ensure the trade financing business achieve the desired results, aid small and medium-sized enterprises to make the international trade business develop and grow.

\subsection{Strengthen the government's macro control}

At present, small and medium-sized enterprises have become an important part of China's economic development. The government should strengthen their macro control, improve relevant laws and regulations, effectively play its administrative function, and provide legal guarantees for the trade financing of small and medium-sized enterprises. First, establish a development fund for small and medium-sized enterprises to help and support their development, effectively stimulate their development potential, and further dredge the hidden barriers in trade financing for these enterprises. Second, guide financial institutions to focus on small and medium-sized enterprises, develop multilevel and diversified market financing channels, as well as implement preferential tax policies for financial institutions that serve small and medium-sized 
enterprises. Third, establish and improve the legal system related to credit financing for small and mediumsized enterprises as well as appropriately increase the intensity of credit supply along with targeted and precise implementation of financing policies to create favorable conditions for the international trade financing of small and medium-sized enterprises.

\subsection{Expand financing channels and increase the proportion of direct financing}

A number of small and medium-sized science and technology-based enterprises that are in line with national industrial policies, with market-oriented products, leading technology, and great development potential should be cultivated and supported to venture into Shanghai and Shenzhen Stock Exchange for listing and financing on the Science and Technology Innovation Board and Growth Enterprise Market. Measures for the Administration of Material Assets Reorganization of Listed Companies should be reserved and improved; listed companies should be encouraged to create more listing opportunities for small and medium-sized enterprises through asset restructuring, mergers and acquisitions, as well as direct financing.

\section{Conclusion}

The implementation of One Belt, One Road policy basically forms a pattern of interconnection between countries along the line, and it also provides a relatively stable international business environment for the growth and development of small and medium-sized enterprises in China. In recent years, the scale and efficiency of small and medium-sized enterprises in China have increased significantly. However, the financing funds of small and medium-sized enterprises do not match their status in the national economic system. The high threshold of international trade financing as well as the large-scale, long-term, and highrisk characteristics of international trade capital flow would lead to the widespread shortage of funds in small and medium-sized enterprises, thus affecting the long-term development of the international trade of these enterprises. Therefore, it is urgent to solve the financing problem of small and medium-sized enterprises. Through in-depth analysis of the problems in international trade financing of small and medium-sized enterprises and their root causes, as well as the implementation of targeted measures to carry out financing work, the cooperation between government support and financial institutions is indispensable in the face of complex and changeable domestic as well as international economic environment. At the same time, it also requires enterprises to improve their comprehensive strength, including risk protection capability, credit construction, adaptability, etc., which would promote enterprises to give full play to the advantages of independent development, obtain more secure, convenient, low-cost financing funds, and win opportunities in laying the foundation for the future development of these enterprises.

\section{Disclosure statement}

The author declares that there is no conflict of interest.

\section{References}

[1] Yin Y, 2018, Analysis of International Trade Financing Problems of China's Small and Medium-Size Enterprises in the New Era. Hebei Enterprise, (10): 118-9.

[2] Wu Y, 2020, International Trade Financing of Small and Medium-Size Enterprises. Fortune Today, (19): 25-6.

[3] Ye M, 2021, Research on the Problems and Countermeasures of International Trade Financing of Small and Medium-size Enterprises. China Small and Medium Enterprises, (03): 170-1.

[4] Liu J, 2019, Risk Analysis of International Trade Financing of Small and Medium Enterprises in China. 
Inner Mongolia Coal Economics, (23): 107-8.

[5] Zhu Y, 2018, Analysis of International Trade Financing Risks of Chinese Small and Medium-sized Enterprises in the Context of International Financial Turbulence. Management and Technology of Small and Medium-size Enterprises (Medium Issue), (12): 150-1.

[6] Zhou D, 2019, Financing Difficulties of Small and Medium-Size Enterprises in International Trade. Times Finance, (20): 74, 78.

[7] Wang H, 2019, A Study on the Trade Financing of Small and Medium-Sized Enterprises. Finance and Economics, (30): 67.

[8] Cao X, 2019, Research on International Trade Financing of Small and Medium-Size Enterprises in China. Fortune Today, (14): 116.

[9] Liang X, 2019, The Problem of International Trade Financing for Small and Medium-Size Enterprises. Time Finance, (29): 65-6.

[10] Zhang Y, Liu C, 2019, Problems and Solutions of International Trade Financing for Small and Medium-Sized Enterprises. Time-Honored Brand Marketing, (03): 49-51. 